\title{
Combination of Cow Manure Rate and Different Sources of Nitrogen Humite on the Nutritional Content and Yield of Aloe vera L. Plant in Sandy Soil
}

\author{
Maria Theresia Darini ${ }^{\mathrm{a}}$, Endang Sulistyaningsih ${ }^{\mathrm{b}}$ \\ ${ }^{a}$ Faculty of Agriculture, Universitas Sarjanawiyata Tamansiswa, Yogyakarta, Indonesia \\ E-mail:darini@ustjogja.ac.id \\ ${ }^{b}$ Faculty of Agriculture, Universitas Gadjah Mada, Yogyakarta, Indonesia \\ E-mail: endangsih@ugm.ac.id
}

\begin{abstract}
Aloe vera L. plants contain various kinds of chemical compounds that are very beneficial for health, so this plant needs to be developed. The limited availability of fertile lands has resulted in the aim of making sandy soil potential for Aloe vera cultivation. The experiment was arranged in a Randomized Complete Block Design with three replications. The first factor was the rate of cow manure, i.e., 30 and $45 \mathrm{tha}^{-1}$. The second factor was nitrogen sources of $300 \mathrm{~kg} \mathrm{ha}^{-1}$ with $15 \%$ addition of humic fertilizer, i.e., urea, AS, NPK, KNO3, humic urea, humic AS, humic NPK, and humic KNO3. The variables measured include water content, protein, fat, carbohydrate, crude fiber, ash, and fresh weight of the leaves. The data were analyzed using analysis of variance at $5 \%$ of significance then followed by Duncan's Multiple Range Test at $5 \%$ of significance. The results showed that there was a significant interaction between rates of cow manure and a source of humic nitrogen on all variables. The highest leaf nutrition content was obtained at a rate combination of $30 \mathrm{t} \mathrm{ha}^{-1}$ of cow manure with humic AS, while the carbohydrate content was obtained using a combination of $45 \mathrm{t}$ ha ${ }^{-1}$ of manure with KNO3 or urea humic acid. The highest growth and yield of the plants was obtained at a combination among $30 \mathrm{t}$ ha ${ }^{-1}$, manure, and humic urea.
\end{abstract}

Keywords — aloe vera; nitrogen humic; nutrition content; yield.

\section{INTRODUCTION}

The Aloe vera plant has been used as an ornamental plant, as an ingredient in health foods, for the cosmetic industry, and as a medicinal plant. This plant is, therefore multifunctional, and has been dubbed a Miracle Plant. The leave of this plant contains fat compounds, carbohydrates, proteins, 18 essential amino acids, four kinds of vitamins, minerals, and six kinds of enzymes. The leave of Aloe Vera also contains secondary metabolites, including alkaloids, aloins, lectins, lignin, saponins, tannins, phenolic, and glucomannan. The synergistic activity of all these active substances contributes to the efficacy of the aloe leaves. Aloe vera leaves can be used to improve hair growth, cell regeneration, immunity, to heal wounds and skin irritations. It also works as an anti-inflammatory, an antiseptic, an antibiotic, an antioxidant, an anti-cancer, an anti-cholesterol and an anti-diabetic. As a result, the Aloe vera leaf is currently being used as an ingredient in Phytotherapeutics [1]. It can also be used as a hair styling gel and works exceptionally well for curly or for fuzzy hair. It is also used for makeup moisturizers, soaps, sunscreen, shampoos, and lotions. Aloe vera gel is useful for dry skin conditions, especially the eyes and sensitive facial skin, its juice may help some people with ulcerative colitis an inflammatory bowel disease. Aloe has been marked as a remedy for coughs, wounds, ulcers, gastritis, diabetes, cancer, headache, arthritis, immune system, deficiencies, and many other conditions when taken internally. However, the general external use is as a laxative. The lower leaf of the plant is used for medicinal purposes [2]. Aloe vera gel could be an excellent edible coating material and should be used commercially as a technologically viable postharvest preservation technique for fresh products [3]. Based on the benefits of Aloe vera, its cultivation needs to be expanded, and the land is needed for its development. There has been the conversion of arable land into non-agricultural areas in Yogyakarta Special Territory, encompassing about 200 hectares each year. The need for non-agricultural land tended to increase. This encouraged the conversion of agricultural lands, and if it was not regulated, it might threaten the food resilience Food Agricultural Land Protection policy regulation. So far, several studies had been 
conducted as a basis of the regulation formulation. The main obstacles were previous spatial planning policy, disobedience to the spatial planning regulations, budget allocation, interest groups, farmer's willingness, and agricultural land availability. To strengthened regional food resilience, the Government of Bantul Regency reviewed spatial planning policy, enforced the law of spatial planning regulations, supported budget allocation, set the Sustainable Food Agricultural Land Protection regulation, increased land productivity, and protected existing agricultural lands. Although generally, the condition of food resilience of the Bantul Regency was in the medium category, Sustainable Food Agricultural Land Protection regulation must be implemented immediately [4]. For the development of this plant, the land is needed, while the available arable land has decreased and undergone conversion.

Available land is marginal land in the form of sandy soil. Up till now, the handling of sandy soil is still relatively inadequate. Java Island has $81,000 \mathrm{~km}^{2}$ area of seaside potential to be developed as agricultural land. The Special Region of Yogyakarta has an expanse of coastland covering approximately 3, 300 hectares, or $4 \%$ of the total area, extending $110 \mathrm{~km}$ on the south coast of the Indonesian. The ocean stretch of sand is between $1-3 \mathrm{~km}$ from the coastline. The coastland is marginal land with low water storage capacity, extremely high soil temperature during the day, wind speed, and evaporation rate, sandy textures, loose structure, low nutrient content, low cation exchange capability (CEC). The available arable land has decreased due to land conversion, while the only available land is a marginal one in the form of sandy soil. To improve the properties of sandy soil, an innovative technique is required in the form of ameliorants materials available at the location, such as compost, animal manure, and humic substance [5]. Sandy soil is often dry, nutrient deficiency, and fast-draining [6]. They have little or no ability to transport water from deeper layers, through capillary transport. Therefore, tillage of sandy soil in the spring should be kept to a minimum to retain moisture in the seedbed. The nutrient and water holding capacity of sandy soil can be improved by adding organic material.

An effort to increase soil aggregation and productivity of sandy land was by using organic material which has been decomposed [7]. Compost application could increase soil aggregation and affected other soil physical properties, such as soil temperature, improving water holding capacity, and decreasing drainage. Manure application could increase grain protein content $5.6 \%$, carbohydrate content $7.8 \%$, number of filled spikelet $3.1 \%$, and grain yield $7.9 \%$. The application of organic fertilizer has a weakness of low nutrient content, bulky and slow-release [8]. Incorporating organic and synthetic fertilizer to soil would provide multiple benefits for improvement of soil chemical, physical and biological properties leading to improve crop yield. However, the application of organic fertilizer includes compost, farmyard, manure, slurry, vermicompost, and feather meal; without additional nitrogen, fertilizer did not give differences on most variables. This suggesting that the application of organic fertilizer was able to reduce synthetic nitrogen.
Combined application of organic and mineral fertilizer can be a proper way of nutrients management to increase yield and quality and to reduce the adverse environmental impact of chemicals and the pertaining cost. Humic substance e. g. humic acid and folic acid cover a wide range of mineral organic compounds including amino acid, peptides, phenol aldehyde, and nucleic acid in abounding with different cations and plays a useful role in the improvement of plant growth and development in the composition of substrates and nutritional solution. Humic acid directly acts as quast hormonal compound and indirectly improves soil physical condition increase the metabolism of soil microorganism, enhance root and stem growth, increase the uptake of nutrient through its chelating, restoration and membrane infiltration, conservation properties. The application of such compounds as humic acid that improves the physical and chemical properties of soil can help us produce high-quality crops and avoid soil erosion. Sulfur-containing humic acid increased the fresh and dry weight and diameter of olive fruits. The better growth and physiological conditions of plants sprayed with sulfur-containing humic acid were related to their higher macronutrient ( $\mathrm{N}, \mathrm{P}$, and $\mathrm{K}$ ) and micronutrient $(\mathrm{Mn}, \mathrm{Zn}, \mathrm{Cu}$, and $\mathrm{Fe}$ ) contents. Consequently, we can produce highquality crops by applying sulfur-containing humic acid [9].

Humic acid had the following effects on crop physiology through improving soil structure [10]. It influenced root fractal as well as nutrient absorption, and humic acid contained the plant growth substance, auxin. The auxinic activity of the humic substance, demonstrated in recent studies, is probably the main biological factor responsible for the positive effects exerted by humic substance on plant physiology. The stimulatory effect on Arabidopsis lateral root development observed in response to a humic substance has been found mainly in the first stages, when cells start to divide, suggesting that humic substance response may involve mechanisms as the stimulation of cell division and differentiation, which it is known to be under the control of auxin. Moreover, physiological, and molecular data suggest brassinosteroids as a putative additional factor through which humic substance could exert their effects on plant development. The capacity of humic products to improve plant growth has been proven in the greenhouse and growth chamber [11]. However, more work is needed in field conditions to determine the modifying effects on humid product efficacy, environmental and management factors, crop type, annual weather pattern, soil type, and fertility management. Longer-term continuation of the field trials would enable some aspect as follows:

- Evaluation of product efficacy for crop economic yield under different weather patterns

- Monitoring of evolving soil health properties, and

- Elucidation of the spatial and temporal variability in crop responses to humic products that may allow for the development of precision application methods like those for other crop inputs (e.g., lime and NPK).

This was in line with a report that the influence of potassium humate on growth rate and nutritional value of Pleurotus florida [12]. Pleurotus florida was grown with different concentration of potassium humate i.e. $10 \%, 20 \%$, $30 \%, 40 \%, 50 \% 60 \%, 70 \%, 80 \%, 90 \%$, and $100 \%$. After 
incubation Pleurotus florida at respective treatment is evaluated for total biomass, protein, fiber, ash, and moisture contents. That addition of humic material in around $60 \%$ of the applied fertilizer, would result in increased total weight, protein content, fat, carbohydrate, crude fiber, ash, and energy of oyster mushroom (Pleurotus florida L.). Therefore, it is necessary to study the effects of combined cow manure rate and different sources of nitrogen humic on the nutritional content of Aloe vera L. plant grown in sandy soil.

\section{MATERIAL AND METHODS}

\section{A. Experiment Site and Plant Material}

Research has been conducted in Poncosari, Srandakan, subdistrict Bantul Regency, Yogyakarta Special Territory, with a temperature of $28-36{ }^{\circ} \mathrm{C}, 100 \%$ light intensity, 64$75 \%$ humidity, and $1672.5 \mathrm{~mm}^{-1}$ year $^{-1}$ rainfall. The research was also conducted in the Crop Production Laboratory of Agriculture Faculty of Universitas Sarjanawiyata Tamansiswa, Biotechnology Laboratory of Agricultural Technology Faculty and Integrated Research and Testing Laboratory of Universitas Gadjah Mada. Materials used in the experiment were cow manure, urea, ammonium sulfate, $\mathrm{NPK}, \mathrm{KNO}_{3}$, humic material from manure, and 1250 two months old seedlings.

\section{B. Experiment design}

The experiment was arranged in a Randomized Complete Block Design, 2 × 8 factorial with three replications. The first factor was that rates of cow manure consist of two levels, i.e., 30 and $45 \mathrm{t}$ ha- 1 . The second factor was nitrogen sources of $300 \mathrm{~kg}$ ha-1 with a $15 \%$ addition of humic fertilizer, which consists of eight levels. These levels were urea, ammonium sulfate, NPK, KNO3, humic urea, humic ammonium sulfate, humic NPK, and humic KNO3. There were 16 combined treatments.

\section{Experimental Procedure}

Experimental procedures consist of the steps as follows:

- Seedling preparations of aloe plants grown in a polybag

- Soil tillage using hoe, land plotting and making planting holes

- Application of manure as a primary fertilizer at 30 and 45 t ha-1.

- Planting the seedlings of two months old, with plant spacing 80 x $80 \mathrm{~cm}$

- Application of various nitrogen source

- Watering was done every day in the afternoon using a sprayer

- Weeding was done manually by removing the weeds grew around the plants, once a month

- The final observation of nutritional contents, growth, and yield were done 12 months after planting.

\section{Data Collection and Statistical Analysis}

The variables for the growth component included the yield of the fresh and dry weight of the leaves. The variables for the nutritional content included water, protein, fat, carbohydrate, ash, and fiber content. All data were analyzed using analysis of variance at a significance level of 5\%, continued by Duncan's Multiple Range Test at a significance level of $5 \%$ for mean comparison.

\section{RESULT AND DISCUSSION}

There was a significant interaction effect between the rate of manure and nitrogen humic source on most variables measured, except for fiber content.

\section{A. Water, Protein, and Fat Content}

1) The leaf water content: The leaf water content presented in Table 1, indicated that nitrogen source did not significantly affect water content in the leaves when combined with cow manure of $30 \mathrm{t} \mathrm{ha}^{-1}$. However, $45 \mathrm{t} \mathrm{ha}^{-1}$ cow manure, combined with ammonium sulfate or NPK, resulted in the highest water content in the leaves. Another study has discussed the influence of potassium humate on growth rate and nutritional value of Pleurotus florida [12]. Pleurotus florida was grown with different concentration of potassium humate i.e. $10 \%, 20 \%, 30 \%, 40 \%, 50 \%, 60 \%$, $70 \%, 80 \%, 90 \%$, and $100 \%$. After incubation Pleurotus florida at respective moisture, the addition of $10-100 \%$ potassium humic did not influence the water concentration of oyster mushroom (Pleurotus florida L.). Different combinations of mineral fertilizers and humic acid $(100 \%$ mineral fertilizers of NPK, the recommended doses of NPK), (75\% mineral fertilizers of NPK $+1 \mathrm{~kg}$ humic acid/fed.), (50 $\%$ mineral fertilizers NPK $+2 \mathrm{~kg}$ humic acid/fed.), $(25 \%$ mineral fertilizers NPK $+3 \mathrm{~kg}$ humic acid/fed.), and (3 kg humic acid/fed.) on two cultivars of wheat that application humic substance significantly decreased water content of wheat cultivar [13].

2) The leaf protein content: The leaf protein content seen in Table 1 revealed that the highest protein content was obtained either at a combination of $30 \mathrm{t} \mathrm{ha}^{-1}$ cow manure combined with ammonium sulfate $/ \mathrm{KNO}_{3}$ with humic acid or at $45 \mathrm{t} \mathrm{ha}^{-1}$ cow manure combined with urea/ $/ \mathrm{KNO}_{3}$ without humic acid. High protein content was obtained when a low rate of manure was combined with humic ammonium sulfate and humic $\mathrm{KNO}_{3}$ or when a high rate of manure was combined with urea. Different combinations of mineral fertilizers and humic acid (100\% mineral fertilizers of NPK, the recommended doses of NPK), (75\% mineral fertilizers of NPK $+1 \mathrm{Kg}$ humic acid/fed.), (50\% mineral fertilizers $\mathrm{NPK}+2 \mathrm{Kg}$ humic acid/fed.), (25\% mineral fertilizers NPK $+3 \mathrm{Kg}$ humic acid/fed.), and (3 Kg humic acid/fed.) on two cultivars that application humic substance significantly increased grain protein content of wheat cultivarKNO $\mathrm{N}_{3}$ [13]. The nitrogen content of urea and $\mathrm{KNO}_{3}$ was relatively high, and humic compound increased nutrient absorption, which eventually resulted in maximal leaf protein content. Foliar spray with green tea extract also showed a significant increase in all the characteristics mentioned above when compared with other treatments except for the treatment at 4 $\mathrm{ml} . \mathrm{L}^{-1}$ potassium humate [14]. While the control treatment gave the lowest values in the means protein total content of the leaf. Also, the results indicate that the control treatment recorded the highest significant increase in the percentage of water content in the guava leaves compared with the other treatments. Foliar application of soluble humates isolated 
from vermicompost promoted organic lettuce yields [15]. Changes in lettuce metabolism occurred in plants treated with humates, including decreased total carbohydrate content, increased total protein content in leaves, and induction of nitrate reductase and phenylalanine ammonialyase activity, which in combination accelerated the production cycle found that application of $15 \mathrm{mg} \mathrm{L}^{-1}$ humic acid increased the protein content of lettuce. Cyprus olive trees responded positively to soil application of $0.25 \mathrm{~m}^{3}$ cattle manure added for each tree once time in the first week of January and $150 \mathrm{~cm}^{3}$ humic acid added to the soil once time in the first week of March (at the begging of growing and blooming) [16]. Next, $150 \mathrm{~cm}^{3}$ pigeon manure tea +150 $\mathrm{cm}^{3}$ green power added to the soil once time in the first week of Jun, recorded highest, the increment in moisture percentage olive than the control reached about $35 \%$ and 69 $\%$ in the first and second season respectively.

TABLE I

WATER, PROTEIN, AND FAT CONTENT (\%)

\begin{tabular}{|c|c|c|c|c|c|c|}
\hline \multirow{3}{*}{ Nitrogen Source } & \multicolumn{2}{|c|}{ Water Content (\%) } & \multicolumn{2}{|c|}{ Protein Content (\%) } & \multicolumn{2}{|c|}{ Fat Content $(\%)$} \\
\hline & \multicolumn{2}{|c|}{ Cow Manure Rate } & \multicolumn{2}{|c|}{ Cow Manure Rate } & \multicolumn{2}{|c|}{ Cow Manure Rate } \\
\hline & $30 \mathrm{t} \mathrm{ha}^{-1}$ & $45 \mathrm{t} \mathrm{ha}^{-1}$ & $30 \mathrm{tha}^{-1}$ & $45 \mathrm{t} \mathrm{ha}^{-1}$ & $30 \mathrm{tha}^{-1}$ & $45 \mathrm{t} \mathrm{ha}^{-1}$ \\
\hline Urea & $96.47 \mathrm{a}$ & $96.16 \mathrm{~b}$ & $0.24 \mathrm{~d}$ & $0.36 \mathrm{a}$ & $0.060 \mathrm{c}$ & $0.086 \mathrm{bc}$ \\
\hline AS & $96.26 \mathrm{a}$ & $96.75 \mathrm{a}$ & $0.25 \mathrm{~cd}$ & $0.26 \mathrm{~d}$ & $0.080 \mathrm{ab}$ & $0.117 \mathrm{a}$ \\
\hline NPK & $96.61 \mathrm{a}$ & $96.85 \mathrm{a}$ & $0.26 \mathrm{~cd}$ & $0.25 \mathrm{de}$ & $0.070 \mathrm{bc}$ & $0.086 b c$ \\
\hline $\mathrm{KNO}_{3}$ & $96.30 \mathrm{a}$ & $96.18 \mathrm{~b}$ & $0.27 \mathrm{bc}$ & $0.32 \mathrm{a}$ & $0.080 \mathrm{ab}$ & $0.083 b c$ \\
\hline Urea HA & $96.33 \mathrm{a}$ & $96.08 \mathrm{~b}$ & $0.29 \mathrm{~b}$ & $0.28 \mathrm{~b}$ & $0.076 \mathrm{~b}$ & $0.073 \mathrm{c}$ \\
\hline AS HA & $96.56 \mathrm{a}$ & $96.68 \mathrm{a}$ & $0.32 \mathrm{a}$ & $0.27 b$ & $0.093 \mathrm{a}$ & $0.093 b$ \\
\hline NPK HA. & $96.52 \mathrm{a}$ & $96.51 \mathrm{ab}$ & $0.25 \mathrm{~cd}$ & $0.27 \mathrm{~b}$ & $0.083 \mathrm{ab}$ & $0.090 \mathrm{~b}$ \\
\hline $\mathrm{KNO}_{3} \mathrm{HA}$. & $96.42 \mathrm{a}$ & $96.29 \mathrm{~b}$ & $0.32 \mathrm{a}$ & $0.27 \mathrm{~b}$ & $0.073 \mathrm{bc}$ & $0.073 \mathrm{c}$ \\
\hline
\end{tabular}

Note: Means within each column followed by the same letter are not significantly different using Duncan's Multiple Range Test at $5 \%$ significant level.

3) Leaf fat content: Table 1 shows that the lowest leaf fat content was obtained with the combination of $30 \mathrm{t} \mathrm{ha}^{-1}$ cow manure and urea, as well as with $45 \mathrm{t} \mathrm{ha}^{-1}$ manure combined with humic urea or humic $\mathrm{KNO}_{3}$, while high-fat content was obtained with the addition of ammonium sulphate. Cyprus olive trees responded positively to soil application of $0.25 \mathrm{~m} 3$ cattle manure added for each tree once time in the first week of January [16]. Next, 150 $\mathrm{cm} 3$ humic acid added to the soil once time in the first week of March (at the begging of growth and blooming). $150 \mathrm{~cm} 3$ Pigeon manure tea $+150 \mathrm{~cm} 3$ Green power added to the soil once a time in the first week of Jun recorded Highest yield $(\mathrm{kg} /$ tree $)$. The increment in yield $(\mathrm{kg} /$ tree) percentage olive than the control reached about $35 \%$ and $69 \%$ in the first and second season, respectively. The application of mixture manure organic or pigeon combined with actrasol $(20 \%$ humic acid + NPK) could increase the oil content of olive trees. To increase productivity with the low cost of high nutritive substrate with humic acid, it requires paddy straw to created effects [17]. Humic acid is one of good nutritive factors for mushroom cultivation. In this study various concentration of humic acid were taken and treat with paddy straw. The maximum yield $(242 \mathrm{gm})$ of mushroom was found to be in $4 \%$ of humic acid treated paddy straw, followed by $3 \%, 2 \%, 1 \%$, and control (101gm). The lowest yield (96gm) was found to be in $6 \%$ of humic acid treated paddy straw. The nutrients like protein, fibre,fat,and ash were high in $4 \%$ of humic acid treated paddy straw.Outlay benefit analysis exposed that $4 \%$ and $3 \%$ shows potential for the growth of oyster mushroom (Pleurotus ostreatus L.).

\section{B. Carbohydrate, Ash and Fiber Content}

1) Carbohydrate content: The effect of combining manure rate with nitrogen source on carbohydrate content, as presented in figure 1 showing that the lowest carbohydrate content was gained by combined manure. To increase the productivity with low cost of the high nutritive substrate with humic acid, it requires Paddy straw treament [17]. Humic acid is one of good nutritive factor for mushroom cultivation. In this study, various concentrations of humic acid were taken and treat with paddy straw. The maximum yield $(242 \mathrm{gm})$ of mushroom was found to be in $4 \%$ of humic acid treated paddy straw, followed by $3 \%, 2 \%, 1 \%$, and control (101gm). The lowest yield (96 gm) was found to be in $6 \%$ of humic acid treated paddy straw. The nutrients like protein, fiber, fat, and ash was high in $4 \%$ of humic acid treated paddy straw. Outlay benefit analysis exposed that the $4 \%$ and $3 \%$ shows potential for the growth of oyster mushroom, whereas the highest carbohydrate content was obtained when $45 \mathrm{t} \mathrm{ha}^{-1}$ cow manure was combined with humic urea. That $3 \%$ humic acid influenced the carbohydrate content of Pleurotus ostreatus, likewise of [18] reported that that ammonium sulfate + organic manure + humic acid caused stimulation of growth characters measured yield as well as berries quality parameters compared to control treatment. Total acidity percentage in the juice tended to reduce using ammonium sulfate + organic manure + humic acid treatments. Application of Ammonium sulfate + organic manure, Ammonium sulfate + Humic acid or organic manure + humic acid caused a significant increase in leaf

Total sugars and Juice density) compared to the application of Ammonium sulfate, Humic acid, and Organic manure alone. Kapplication organic manure combined with humic acid could increase carbohydrate content of grape cv Kamali. The best treatment in reducing $\mathrm{Al}$ and $\mathrm{Fe}$-ecxh to soil there was giving 800 ppm humic matter and $100 \%$ R P fertilizer by incubation $\mathrm{I} 3$, a decline value from 3.42 to 1.77 me $(100 \mathrm{~g})^{-1}$ for Al-ecxh and from 70.35 to $53.48 \mathrm{ppm}$ for Fe-ecxh of soil [19]. The best treatments interactions that increased the availability of $\mathrm{P}$ soil and $\mathrm{P}$ nutrient content of corn is the way $\mathrm{I} 3$ incubation at providing a combination of humic matter and P fertilizer dose $800 \mathrm{ppm}+100 \%$, almost the same as the dose of $800 \mathrm{ppm}+75 \%$, and increases $\mathrm{P}$ available for 17.19 and $12.86 \mathrm{ppm}$ than dose $400 \mathrm{ppm}+100 \%$ 
$\mathrm{R}$ and $400 \mathrm{ppm}+75 \% \mathrm{R}$. Treatment which is give the maximum yield of corn on $800 \mathrm{ppm}$ humic matter and $100 \%$ $\mathrm{R} P$ fertilizer by incubation I3 , the amount of yield $9.21 \mathrm{t}$ ha ${ }^{-1}$. However, this result is almost the same as giving $800 \mathrm{ppm}$ humic matter $+\mathrm{P}$ fertilizer $75 \%$ recommendation by incubation humic matter and $\mathrm{P}$ fertilizer mixed for 1 week, then incubation to the soil for 1 week $\left(\mathrm{I}_{3}\right)$. This suggests that treatment of humic matter and $\mathrm{P}$ fertilizer can save up $\mathrm{P}$ fertilizer to $25 \%$. combined of humic $\mathrm{K}$ and organic fertilizer achieved better values of carbohydrate content percentage of sweet pepper.

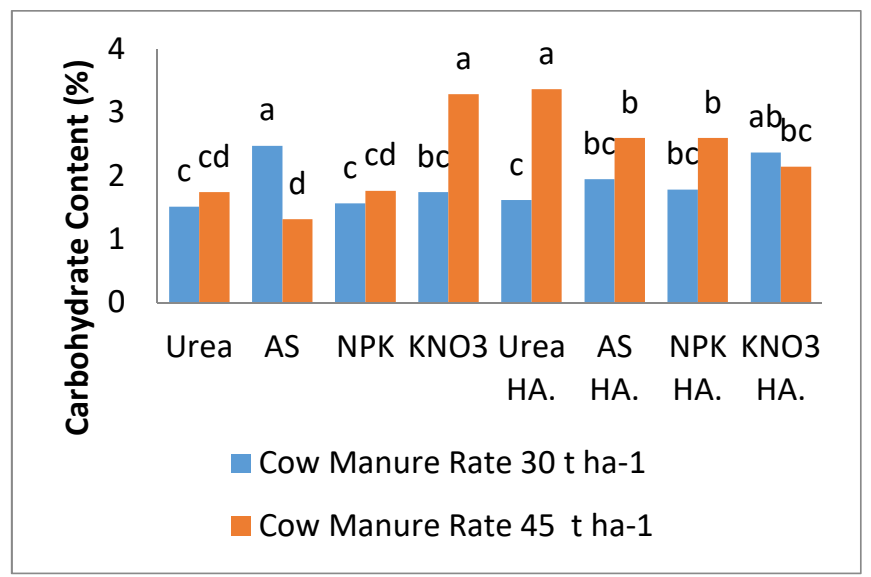

Fig. 1 Carbohydrate content as affected by combination of cow manure rate and different sources of humic nitrogen

4) Ash content: The highest ash content (Figure 2) was obtained when a manure rate of $45 \mathrm{tha}^{-1}$ was applied with ammonium sulfate. Otherwise, no significant difference was found between nitrogen sources. Another scholar has discussed the influence of potassium humate on growth rate and nutritional value of Pleurotus florida [12]. Pleurotus florida was grown with different concentration of potassium humate i.e. $10 \%, 20 \%, 30 \%, 40 \%, 50 \%$ 60\%, 70\%, $80 \%$, $90 \%$, and $100 \%$. After incubation Pleurotus florida at respective moisture, the addition of $10-100 \%$ potassium humic did not influence the increasd ash concentration of oyster mushroom (Pleurotus florida L.). To increase productivity with the low cost of high nutritive substrate with humic acid, it requires paddy straw treatment [17]. Humic acid is one of good nutritive factor for mushroom cultivation. In this study, various concentrations of humic acid were taken and treat with paddy straw. The maximum yield $(242 \mathrm{gm})$ of mushroom was found to be in $4 \%$ of humic acid treated paddy straw, followed by $3 \%, 2 \%, 1 \%$ and control (101gm). The lowest yield (96gm) was found to be in $6 \%$ of humic acid treated paddy straw.The nutrients like protein, fibre,fat,and ash was high in $4 \%$ of humic acid treated paddy straw.Outlay benefit analysis exposed that the $4 \%$ and $3 \%$ reported in Pleurotus ostreatus L., that it did not agree with the present finding.

5) Fiber content: Fiber content presented in Figure 3 showed that combination of manure with ammonium sulphate, with and without addition of humic acid, revealed the highest fiber content. To increase the productivity with low cost of high nutritive substrate with humic acid, the paddy straw treatment is needed [17]. Humic acid is one of good nutritive factor for mushroom cultivation. In this study various concentration of humic acid were taken and treat with paddy straw. The maximum yield (242 gm) of mushroom was found to be in $4 \%$ of humic acid treated paddy straw, followed by $3 \%, 2 \%, 1 \%$ and control (101 gm). The lowest yield $(96 \mathrm{gm})$ was found to be in $6 \%$ of humic acid treated paddy straw.The nutrients like fibre was high in $4 \%$ of humic acid treated paddy straw. Outlay benefit analysis exposed that the $4 \%$ and $3 \%$ shows potential for the growing of oyster mushroom, whereas the highest fiber content was obtained when $45 \mathrm{t} \mathrm{ha}^{-1}$ cow manure was combined with humic urea 3\% of Pleurotus ostreatus.

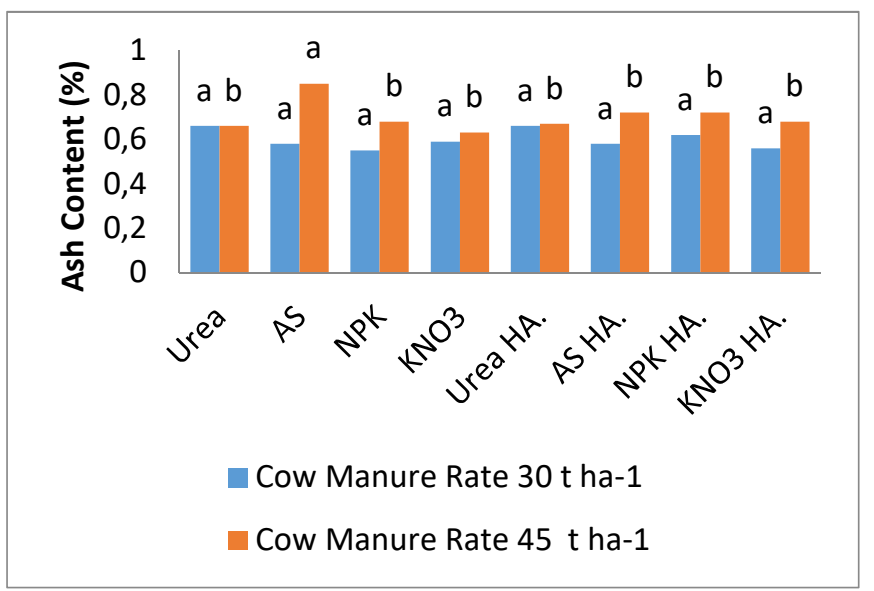

Fig. 2 Ash content as affected by combination of cow manure rate and different sources of humic nitrogen

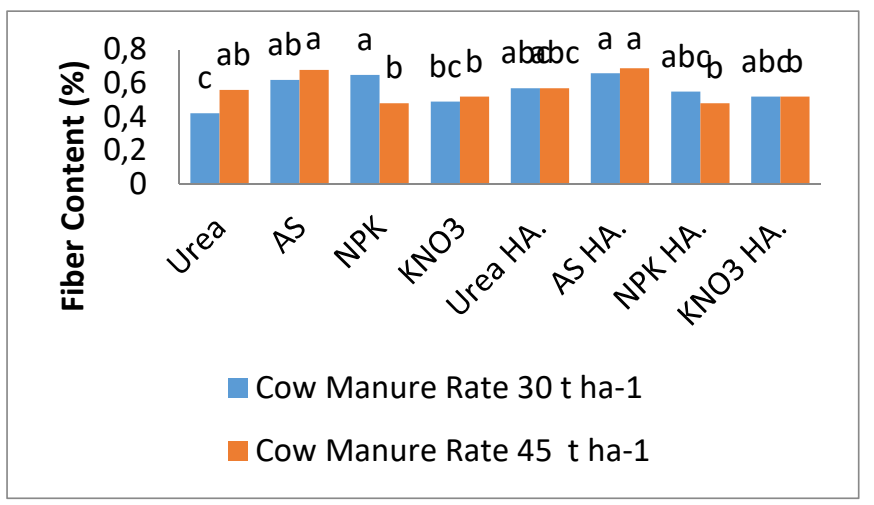

Fig. 3 Fiber Content as affected by a combination of cow manure rate and different sources of humic nitrogen

\section{Leaf Fresh Weight, Leaf Dry Weight, and Yield}

1) The fresh and dry weight: The fresh and dry weight of the leaves and the corresponding yields were presented in Figure 4 and 5. The leaf fresh and dry weight was increased by the addition of humic material combined with the manure of $30 \mathrm{t} \mathrm{ha}^{-1}$ up to $45 \mathrm{t} \mathrm{ha}^{-1}$ with urea. Humic acid can improve physical soil properties and root absorption. Mineral fertilizers are the major nutrient input source to improve crop productivity [20]. In the meantime, the use of inorganic fertilizers alone may cause problems for human health and the environment and so the need to integrate the organic and inorganic fertilizers is necessary to achieve better crop yields and quality as well as improve physical, biological, and chemical properties of the soil. Thus, the obtained results from this study emphasized that the best 
treatment was (NPK 75\%) x (Kalium humat + amino acid) $\mathrm{x}$ (Sodium selenit $10 \mathrm{ppm}$ ), which gave the optimum values of all growth and yield tested the character of sweet pepper plant. To determine the effects of two dose $\left(0,40 \mathrm{mg} \mathrm{kg}^{-1}\right)$ of fulvic acid (FA) and four doses (0, 40, 80 and $120 \mathrm{mg} \mathrm{kg}^{-}$ ${ }^{1}$ ) of humic acid (HA), it requires treatments on growth parameters of Impatients walleriana L [21]. The experiment results showed that treatments of HA $\left(40 \mathrm{mg} \mathrm{kg}^{-1}\right)$ and FA (40 mg kg-1) enhanced the growth significantly when compared to the control groups. This results shows the promoting effects of HA and FA on plant growth variables as fresh root weight, dry root weight, fresh shoot weight, and dry shoot weight, the addition of humic matterial up to 800 ppm increased fresh weight of corn and can save P fertilizer up to $25 \%$, while another reported that application humic and fulvic acid $40 \mathrm{mg} \mathrm{kg}^{-1}$ could increase the dry and fresh weight of leaf Impatien walleriana L. plant. To elucidate the effect of humic acid (HA) and NAA to determine the chemical, biochemical parameters, and productivity of linseed [22]. The eighteen-treatment included different concentrations of humic acid (300, 350, 400, 450 and 500 ppm) and NAA (25 and $50 \mathrm{ppm}$ ) individually and in combinations applied under randomized block design (RBD) replicated thrice.

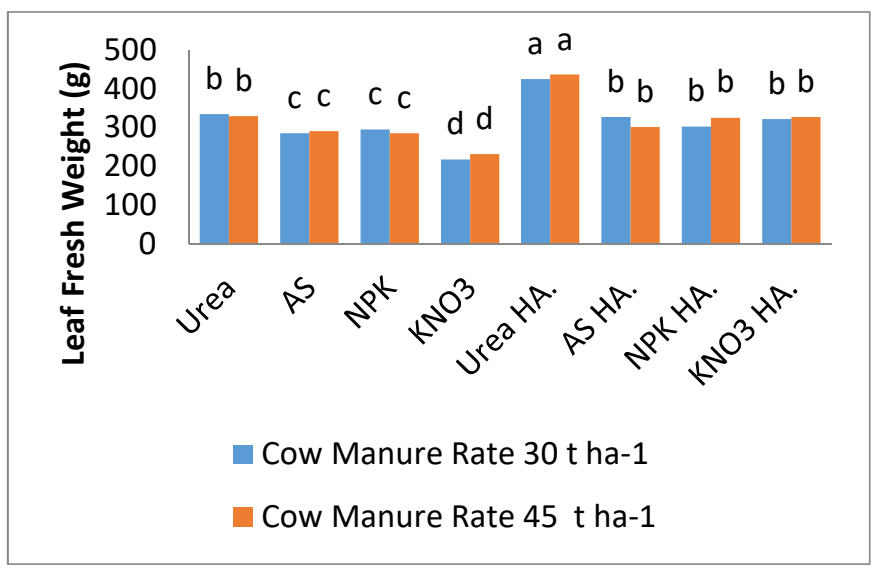

Fig. 4 Fresh weight of leaf as affected by combination of cow manure rate and different sources of humic nitrogen.

All the chemical, biochemical and yield attributes significantly influenced by the foliar spraying taken at 35 and 55 DAS of humic acid through vermicompost wash and NAA and obtained results revealed that treatment T15 (350 ppm HA through VCW +50 ppm NAA) as the most effective one compared with the control (water spray) and other treatments. From the overall results it can be concluded that foliar nutrition through humic source such as VCW and NAA with different concentrations improved chemical and biochemical and yield and yield contributing characters significantly. The highest per cent increased in yield over control was observed in foliar application of 350 ppm HA through VCW + 50 ppm NAA (T15) i.e. 44\%. Next to this treatment foliar spray of $300 \mathrm{ppm}$ HA through VCW + 50 ppm NAA (T14) also enhanced linseed yield $42 \%$ over control. To determine the effect of humic acid (HA) on the yield and nutritional characteristics of cowpea varieties, it requires to provide an alternative crop for sustainable agricultural systems [23]. Field trials were carried out for 2 years in Konya/Turkey ecology. HA was applied in 4 doses $\left(0,70,110\right.$ and $150 \mathrm{~kg} \mathrm{ha}^{-1}$ in total) on 2 cowpea varieties (Akkiz and Karagoz) and a total of 20 parameters were evaluated. Results showed that, 1000 seed weight, seed yield, protein yield, potassium and manganese showed an increasing tendency by increased dose of humic acid. Furthermore, $70 \mathrm{~kg} \mathrm{ha}^{-1}$ dose of humic acid recorded higher stomatal conductance and first pod height, while applicationof $110 \mathrm{~kg} \mathrm{ha}^{-1}$ of humic acid recorded higher plant height and protein ratio. Future research related with nutritional values is needed for achieving better growing techniques and mineral composition in cowpea genotypes. Based on reported that the combination of cow manure doses of $25 \mathrm{Mg}$ per ha, nitrogen fertilizer with addition of $350 \mathrm{ppm}$ humic acid increased the fresh weight of cowpea.

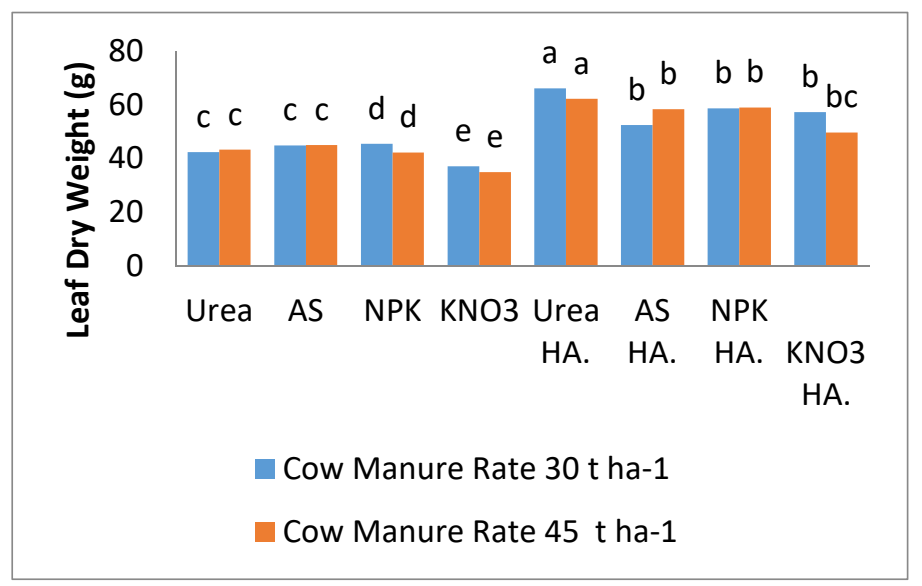

Fig. 5 Dry weight of leaf as affected by combination of cow manure rate and different sources of humic nitrogen.

2) The yield: The yield of the first harvest Figure 4 revealed that low yield was obtained at the application of 30 or $45 \mathrm{t} \mathrm{ha}^{-1}$ cow manure combined with $\mathrm{KNO}_{3}$, and the highest yield was gained by the addition of humic material in combined manure of $30 \mathrm{t}$. The experiment consists of six treatments viz full of recommended dose of chemical fertilizer (NPK), CDHA at $30 \mathrm{~kg} \mathrm{ha}^{-1}$ along with one third reduced application of recomd [24]. NPK, PDHS at $300 \mathrm{~L}$ $\mathrm{ha}^{-1}$ along with one-third reduced application recomd. NPK, CDHA@ $30 \mathrm{~kg} \mathrm{ha}{ }^{-1}$ ) along with one-third recomd. NPK+MN, PDHA (plant derived humic acid) @300 1 ha ${ }^{-1}$ along with one third reduced application recomd. NPK+MN, CDHA@200 $\mathrm{mg} \mathrm{L}^{-1}$ ), Foliar along with one third recomd. $\mathrm{NPK}+\mathrm{MN}$. Plant and coal derived humic substances have important effects on plant growth. The humic substances, along with fertilizer and micronutrients, increased the yield significantly and saved $25 \%$ cost of production. It is time to use plant waste materials and coal by converting into humic substances. The soil fertility level is also increased, and production is increased. That addition of humic material of $70 \mathrm{~kg} \mathrm{ha}^{-1}$ could increase potato (Solanum tuberosum L.) yield to study the effects of humic substances on yield and quality of two lettuce cultivars (Dark Green and Big-Bell) [25]. The experiment included 7 treatments; (T1) 50\% mineral recommended NPK with humic substances extracted from biogas manure as foliar treatment (HBF); (T2) 50\% 
NPK with humic substances extracted from the compost as foliar treatment (HCF); (T3) 50\% NPK with humic substances of biogas manure as drench soil treatment (HBS); (T4) 50\% NPK with humic substances of compost as drench soil treatment (HCS); (T5) 50\% NPK+HBF+HCS; (T6) 50\% $\mathrm{NPK}+\mathrm{HBS}+\mathrm{HCF}$, and (T7) $100 \%$ mineral recommended NPK (control). The application of Grow Flow 45H (humic acid multinutrient liquid fertilizer) at recommended dose increased the tuber yield by $9.3 \%$ as compared to chemical fertilizer [26]. Nitrogen $(\mathrm{N})$, phosphorus $(\mathrm{P})$ and potassium (K) content of the Grow Flow $45 \mathrm{H}$ treated plants were 2.89, 0.33 and $1.58 \%$ in shoots and $1.89,0.21$ and $1.03 \%$ in tubers, respectively which were significantly higher than the other treatments Grow Flow $45 \mathrm{H}$ increased the N, P and $\mathrm{K}$ use efficiencies by $16.4 \%, 9.3 \%$ and $18.3 \%$ respectively over chemical fertilizer. Though HA-NPK complex fertilizer (developed in the laboratory) was not significantly different from chemical fertilizer in respect of potato yield. The composition and structure of humic acid (HA) can be affected by fertilization, but the short-term effects are difficult to detect using traditional analysis methods [27]. Using a 35-year long-term experiment in Black Soil, the molecular structure of HA was analyzed with Fourier transform infrared spectroscopy (FTIR), ${ }^{13} \mathrm{C}$ nuclear magnetic resonance spectroscopy (NMR), and fluorescence spectroscopy. Variation in HA was analyzed after long-term fertilization, including fertilization with manure (M), inorganic $\mathrm{N}, \mathrm{P}$ and $\mathrm{K}$ fertilizer (NPK), manure combined with inorganic $\mathrm{N}, \mathrm{P}$, and $\mathrm{K}$ fertilizer (MNPK), and a nofertilizer control (CK). The application of each fertilizer treatment increased crop yields compared with the CK treatment, and the MNPK treatment increased crop yield the most. FYM addition at the rate of $20 \mathrm{~m} 3$ gave higher values than $10 \mathrm{~m} 3$ addition in all studied characteristics except crude fiber \%, NO3-N (ppm) and bulb moisture\% in both seasons [28]. Sulphur fertilizer at $200 \mathrm{~kg} / \mathrm{fed}$. caused superiority in the same studied parameters except crude fiber\%, NO3-N ppm and bulb Moisture \% in both seasons. Humic acid fertilizer at the rate of $15 \mathrm{~kg} / \mathrm{fed}$. achieved highest values comparing to other treatments in all estimated parameters in both seasons except crude fiber\%, bulb moisture\% in both seasons and NO3-N (ppm) in the second season. The interaction among 20m3 FYM, 200kg/fed. Sulphur and $15 \mathrm{Kg} / \mathrm{fed}$. humic acid gave significant increases in dry weight (g/plant) and total yield (t/fed.) accumulation decreased in both seasons.

Humic acid (HA) might benefit plant growth by improving nutrient uptake, plant yield, fruit yield, plant physiological parameters [29]. Humic acids have been complexed with sodium $(\mathrm{Na})$, potassium $(\mathrm{K})$, magnesium $(\mathrm{Mg})$, zinc $(\mathrm{Zn})$, calcium $(\mathrm{Ca})$, iron $(\mathrm{Fe})$, copper $(\mathrm{Cu})$ and with various other elements to overcome an element deficiency in soil. Humic acid serves as a catalyst in promoting the activity of microorganisms in soil, so, some studies were conducted that effects of humic acid different plants in field and greenhouse conditions. In wheat: application of humic acid were more effective than potassium alone and could increase grain yield of wheat, likewise the reported application of humic acids $1000 \mathrm{ppm}$ can be increase yield of Amaranthus, broccoli and tomato plant. The highest tuber yield was obtained at combined of application of NPK $75 \%$ of recommended dosage with $16 \mathrm{~kg}$ $\mathrm{ha}^{-1}$ humic potassium [30]. Potassium humate is one of the alternate sources of organic matter for improving physicchemical properties of soils, crop growth and yield [30]. The study investigated the effect of using different rates of potassium humate with and without recommended inorganic fertilizers in clayey loam soil on yield and economics of potato production. Four field experiments were conducted during 2010-11 and 2011-12 by using four levels of each, NPK (0, 50, 75 and $100 \%$ recommended dose) and potassium humate $\left(0,8,12\right.$ and $\left.16 \mathrm{~kg} \mathrm{ha}^{-1}\right)$ in a randomized complete block design (RCBD) with three replications. Application of full rate of NPK fertilizers with $16 \mathrm{~kg} \mathrm{ha}^{-1}$ potassium humate resulted in the highest tuber yield (19.749 tons ha ${ }^{-1}$ ). However, study results of benefit cost ratio indicated that application of NPK at $75 \%$ of recommended dose with $16 \mathrm{~kg} \mathrm{ha}^{-1}$ potassium humate remained the most

economical for potato growers. 3 doses of potassium $(\mathrm{K})(0$, 10 , and $\left.20 \mathrm{~kg} \mathrm{da}^{-1}\right)$ of $\mathrm{K}_{2} \mathrm{SO}_{4}\left(50 \% \mathrm{~K}_{2} \mathrm{O}\right)$ fertilizer and 3 doses of humic acid (HA) (0, 20, and $\left.40 \mathrm{~kg} \mathrm{da}^{-1}\right)(85 \%$ HA) were used [31]. Increase in the HA dose reflected significant effects on $\mathrm{pH}$, salt, organic matter, phosphorus, magnesium, iron, and manganese contents of the experiment area at $p<.01$ level. Increased HA application on plant growth criteria had a significant effect on biological yield, grain yield, and harvest index $(p<.01)$. However, $\mathrm{K}$ did not reflect any effect on the growth stage of wheat. Increased potassium applications influenced the $\mathrm{P}, \mathrm{K}, \mathrm{Mg}, \mathrm{Fe}$, and $\mathrm{Zn}$ contents with a significant level $(p<.01)$. It was observed that HA applications were more effective than potassium applications on both general soil properties and yield and nutrient content.

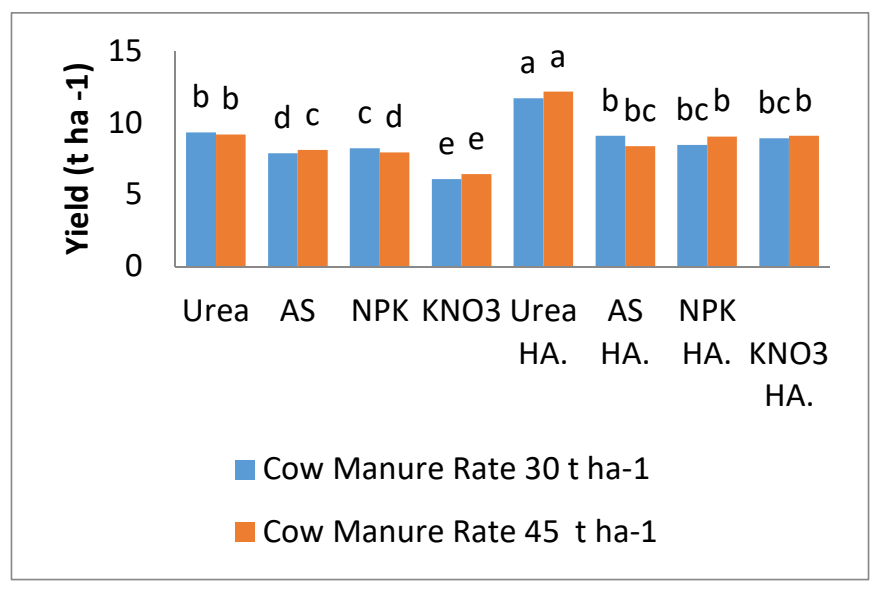

Fig. 6 Yield of first harvest as affected by combination of cow manure rate and different sources of humic nitrogen

\section{CONCLUSIONS}

There was an interaction between the rate combination of cow manure and humic nitrogen source on all observation variables. The leaf nutrition content of high protein, fat, ash, and fiber was obtained at a rate combination of $30 \mathrm{tha}^{-1}$ cow manure and Ammonium Sulphate Humic Acid nitrogen sources, while the carbohydrate content was obtained at combination of $45 \mathrm{t} \mathrm{ha}^{-1}$ manure with $\mathrm{KNO}_{3}$ or Urea Humic Acid. The highest growth and yield of plants was obtained in a combination of $30 \mathrm{tha}^{-1}$ manure with urea Humic Acid. 


\section{ACKNOWLEDGMENT}

The author is grateful to the Ministry of Research, Technology, and Higher Education, for providing financial support for this study through Post Doctor Research Funding.

\section{REFERENCES}

[1] U.Nandal, R. L. Bhardwaj and K. V. Kendra. "Aloe vera a Valuable Wonder Plant for Food, Medicine and Cosmetic Use". Intern. J. Pharmac. Sci. Rev. and Res. vol 13, pp 59- 67, 2012.

[2] R.Rajeswari, M. Umadevi, C. Rahale, R. Pushpa, S. Selvavenhaesh, K.P.S. Kumar and D. Bhwnick. "Aloe vera: The Miracle Plant is Medicinal and Traditional in India." J. of Pharmacognocy and Phytochemistry vol 1, pp $118-124,2012$.

[3] N. Firdous, M. R. Khan, M. S. Butt and M. Shahid "Application of Aloe vera L. gel Based Edible coating to Maintain Postharvest Quality of Tomatoes. "Pak. J. Agri. Sci. vol 5, pp 245 - 249, 2020.

[4] G. I. Janti, E. Martono, dan S. Subejo. "Perlindungan Lahan Pertanian Pangan Berkelanjutan Guna Memperkokoh Ketahanan Pangan Wilayah Kabupaten Bantul DIY "(Protection of Sustainable Food Agriculture Land to Strengthen Regional Food Security in Bantul Special Region of Yogyakarta). Jurnal Ketahanan Pangan (Food Security Journal) vol 22, pp. 1 - 21, 2016.

[5] A. Ma'ruf. "Karakteristik Lahan Pesisir dan Pengelolaannya untuk Pertanian" (Characteristic of Coastal Land and Its Management for Agriculture). http://www.researc, pp 1- 10, 2018.

[6] J.L. Jensen, P. Schjonning, B. T. Christensen, A. L. J. Munkholm." Suboptimal Fertilization Compromises Soil Physical of Hard -setting Sandy Loam. Soil Res. Vol 55, pp 332 - 340, 2016.

[7] M. Tejada, and J. L. Gonzales. "Applications of Two Vermicomposts on Rice Crop. Effect on Soil Biological Properties and Rice Quality and Yield." Agronomy Journal vol 101, pp 336-334, 2009.

[8] Z. Muktamar, D. Putri and N. Setyowati." Reduction of Synthetic Fertilizer for Suatainable Agriculture: Influence of Organic and Nitrogen Fertilizer Combination on Growth and Yield of Green Mustard. Intern. J. Advance Sustainable Engineering Information Technology vol 6, pp $361-364,2016$.

[9] S. Hanssapour, M. A. Baghaee, A. Dayaei and M. Babarabie "The Effect of Sulphur Conatining Humic Acid on Yield and Nutrient Uptake in Olive Fruit." Open J. of Ecology vol 7, pp279 - 288, 2017.

[10] S. Trevisan, O. Francioso, S. Quaggiotti and S. Nardi. "Humic Substances Biological Activity at the Plant Soil Interface from Environmental Aspects to Molecular Factors “. Plant Signaling and Behavior vol 5, pp 635-643, 2010.

[11] D.C. Olk, D.L. Dinnes, J.R. Scoresby, C. R. Callaway and J.W.Darlington. "Humic products in Agriculture Potential benefit and Research Challenges a review “. J. soil and Sediment, vol 18, pp $2881-2891,2018$

[12] P. Prakash, R. Samundeeswari, C. Vivek and A. Chitatradewi. "The Influence of Potassium Humic on Pleurotus florida L." World of Sci. and Technol. vol 1, pp $28-31,2011$.

[13] E.W. Asal, E. B. Elham, O.M. Ibrahim, and E.G. Ghalab. "Can Humic Acid Replace Part of the Applied Mineral Fertilizers? A Study on Two Wheat Cultivar Grown Under Calcareus Soil Condition." Intern. J. of Chem. Technol. Res. vol 8, pp 20 - 26, 2015.

[14] M.A. Ibrahim and E. A. Al-Sereh." Effect of Foliar Spray with Potasium Humate and Green Tea Extract on Some the Vegetative Characteristic of Guava (Psidium guajava L.cv local) Seedling. Plant. Archives $404-408,2019$.

[15] O. Hernandez, A. Calderin, R. Huelva, D.M. Balmori, F. Guridi, N.O. Aguiar, F.O. Olivares and L.P. Canellas. "Humic Substances from
Vermicompost enhance Urban Lettuce Production”. Agron. Sustain. Dev. pp 1-9, 2014.

[16] L.F. Hagag, M.M.M.A. El- Migeed, M.F.M. Shahim, H.A. Mahdy and E.S. El- Hady. "Impact of Organic Fertilizer and Bio-stimulating Substances in Maximizing Productivity and Fruit Quality of cv Cyprus Olive Trees. "Biosci. Res. vol 15, pp3262 - 3269, 2018.

[17] P. Prakash, J. Kennyrakash, A. Bohra, A. Neil, J. Kenny and Sivasubramnian. "Effect of Humic Acid on Pleurotus ostreatus L. Mushroom Cultivation and Analysis Their Nutrient Content." Res. J. of Agric. and Biol. Sci. vol 6, pp. 1067 - 1070, 2010.

[18] H.M.S. Birjely and S.M.M. Al- Atrushy. "Effect of some Organic and Nonorganic Fertilizers on Some Parameter of Growth and Barriers Quality of Grape cv Kamali. Kufa J. Agric. Sci. vol 9, pp $262-274,2017$.

[19] Herviyanti, Gusnidar and M. Harianti. "Using of Humic Matter from Lowrank Coal to Increase Phosphor Fertilizer Efficiency and Production of Corn at Oxisol ". Intern. J. Advant. Sci. Engin. Inform. Technol vol. 3, pp. $21-25,2013$.

[20] M.M. El-Hamady, A.G. Baddor, m.M. Soloh, H.M. Ashor, and H.H.Manaf "Influence of Mineral Fertilization in Combination with K Humate, Amino Acid and Sodium Solution on Growth Chemical Compositio, Yield and Fruit Quality of Sweet Pepper Plant.” Middle East J. of Agric. Res. Vol 6, pp 433 - 447, 2017.

[21] A. Esringu, I. Sezen, B. Aytathi and S. Ercisli. "Effects of Humic and Fulvic Acid Application on Growth Parameter in Impatien walleriana L. "Academic Ziraat Dergisi, vol 4, pp 37 -44, 2015.

[22] M.R. Neware, and P.N. Bobade. "Combined Effect of Humic Acid through Vermicompost and NAA on Biochemical Parameter and Productivity of Linseed “. Intern. J. Curr. Microbiol. App. Sci. Spec. Iss. 6, pp $2682-2691,2018$.

[23] A. Kahraman, "Effect of Humic Acid Doses on Yield and Quality Parameter of Cowpea (Vigna unguiculata L.) Cultivar". Legum Res. vol 40, pp. $155-159,2017$.

[24] A. Khan, R.V. Khan, Z. Khan, F. Hussain, A. Khan, and S.S. Shah "Effect of Humic Substances Alone and in Combination with Micronutrient on Potato Yield and Nutrient Status. Intern. J. of Agro. and Agric. Res. vol 11, pp. $24-29,2017$.

[25] M. M. Shahein, M.M. Afifi, and A.M. Algharib. Study the Effect of Humic Substance on Growth, Chemical Constituent Yield and Quality of Two Lettuce Cultivars (Cv Darkgreen and Bigbell). J. Matter Environ. Sci. Vol. 6, pp. 473 - 486, 2015.

[26] R. Selladurai and T. J. Purakayastha." Effect of Humic Acid Multinutrient Fertilizers on Yield and Nutrient Use Efficiency of Potato.” J. of Plant Nutrition vol 9, pp 1 - 22, 2015.

[27] J. Zhang, J. Wang, T. An, D. Wei, F. Chi and B. Zhou. Effect of Longterm Fertilization on Soil Humic Acid Composition and Structure in Black Soil.” J. Plose One, vol 12, pp 1 - 14, 2017.

[28] S.M.A. Doklega. "Effect of Farmyard Manure, Sulphure and Humic Acid Fertilization on Onion Productivity. Intern. J. Advanc. Res. in Biological Sci. vol 4, pp 38 - 52, 2017.

[29] M. Turam "Effect of Humic Acid Application on Some Plant Yield Quality Parameters and Nutrient Contents in Tukey.” Intern. Coff. Agric. Biotech and Environ. Enginee vol 6, pp 23 - 32, 2017.

[30] M. Idrees, M. A. Anjum and J. I. Mirza." Potasium Humate and NPK Application Rates Influence Yield and Economic Performance of Potato Crops Grown in Clay Loam Soils "Soil Environ. vol 37, pp 53-61, 2018.

[31] M. Dincoy and F. Sonmez. "The Effect of Potassium and Humic Acid Application on Yield and Nutrient Content of Wheat (Triticum aestivum L. var Delfii) with Same Soil Properties." J. of Plant Nutrition vol 42, pp 2752 - 2772, 2019. 